$[\mathrm{XLeP}]$

\title{
Conditions for hydrofracture and the fluid permeability of accretionary wedges
}

\author{
J.H. Behrmann \\ Institut für Geowissenschaften und Lithosphärenforschung, Unicersität Giessen, Senckenbergstrasse 3, D-6300 Giessen, Germany
}

Received December 13, 1990; revised and accepted September 1, 1991

\begin{abstract}
The dewatering of fine grained sediment piles in accretionary wedges is controlled by zones of active deformation. Episodic hydrofracture in these zones enhances permeability, enabling fluid flow to be faster than the speed of underthrusting. Here I investigate the mechanics of simultaneous shear failure and hydrofracture in muddy rocks as a function of the faulting mode. The physical properties of model rock types are chosen to represent uncemented mud or cherty/marly mudstones that have undergone significant diagenesis. During thrust faulting, hydrofracture always requires pore fluid pressures in excess of the lithostatic load, whereas shallow level wrenching or normal faulting permits hydrofracture at hydrostatic pressures significantly lower than lithostatic load. All three faulting modes are expected to occur in an accretionary wedge attempting to dynamically maintain its critical taper. The model computations indicate that in the upper 80-120 $\mathrm{m}$ of a section of "soft" mudstone hydrofracture inevitably accompanies wrench or normal faulting. "Hard" mudstones inevitably hydrofracture to depths of up to $1400 \mathrm{~m}$ during normal faulting. These differences in mechanical behaviour have profound consequences for fluid venting capabilities of accretionary wedges. They influence hydrocarbon trapping, and play a role in the localisation of mud diapirs and mud volcanism.
\end{abstract}

\section{Introduction}

The accretion of sediments at convergent plate margins involves deformation and a very significant reduction in pore space. Pore space reduction necessitates dewatering of the sediment piles [1] by efficient mechanisms. In highly permeable coarse clastic sediments this does not present a problem, but accreted pelagic to hemipelagic sediments have permeabilities [2,3] many times lower than those needed to drive fluids out of accretionary wedges at rates comparable with those of underthrusting [4]. This results in marked underconsolidation of the sediment [3] and build-up of high fluid pressures that can only be relieved instantaneously by the formation of extensional fractures. The development of fracture-related porosity enhances permeability, allowing fluids to escape along fault-defined conduits. At least in the case of the Barbados accretionary wedge [4-7] it was shown that zones of shearing and anomalous pore fluid composition are closely linked. This is taken as evidence for active fluid flow along faults. Formation of extensional veins is also restricted to zones of shearing. Therefore, there appears to be a causal connection between extensional fracturing and shear failure of deforming sediments.

According to recently discussed theories, accretionary wedges are macroscopically ductile [810] and have shapes that are controlled by the rheological properties of the rocks at their bases and those of the rocks constituting the wedges themselves [8]. At a critical angle of taper the wedge is on the verge of failure throughout. This angle of taper varies systematically with changes in mechanical behaviour and in the kinematic framework, i.e. rate and direction of underthrusting. Consequently accretionary wedges are capable of dynamically adjusting their shapes by responding through the three basic modes of faulting [11]. Thrusting and back-rotation of thrust sheets is an elementary mode of wedge thickening, and increases the angle of taper. Wrench faulting is likely to develop if convergence direction changes from frontal to oblique. Normal 
faulting reduces the angle of taper in parts of accretionary wedges that have their geometry changed by large-scale underplating. Localisation of the three faulting modes in an active accretionary wedge and their possible tectonic causes are shown in Fig. 1. Thrusting will be a general and potentially ubiquitous mode of faulting. On the other hand normal faulting is likely to occur in places where the accretionary wedge is oversteepened, for example in the uplifted hanging walls of large duplexes or antiformal stacks. Transcurrent faulting can occur in zones separating areas of low and high rates of accretion. Different rates of accretion along strike of such a complex may be a response to regional differences in sedimentation patterns on the downgoing plate induced by submarine topography (e.g. basement ridges). However, partitioning of deformation into thrusting and transcurrent faulting can be envisaged for any case of oblique plate convergence. In this way every portion of rock can in principle undergo deformation during its material path through an accretionary wedge, and may show a complex history of various modes of faulting.
This paper is concerned with the mechanics of simultaneous shear failure and hydrofracture in argillaceous rocks constituting the frontal and shallow parts of accretionary wedges. I shall attempt to show that the faulting mode is one of the factors that control the efficiency of hydrofracture. The capacity of rocks to hydrofracture is also greatly affected by progressive diagenesis. I shall try to discuss the consequences of this behaviour for the fluid venting capabilities of accretionary wedges.

\section{Simultaneous shear faulting and hydrofrac- ture: mechanical considerations}

This topic has been explored for repeated hydrofracture of indurated rocks before [12]. For the sake of clarity some of the crucial arguments are developed here again. Mean effective stress $\left(\sigma_{\mathrm{m}}^{\prime}\right)[13]$ is defined as:

$\sigma_{\mathrm{m}}^{\prime}=\sigma_{\mathrm{m}}-P$

where $P$ is the hydrostatic pressure and $\left(\sigma_{\mathrm{m}}\right)$ is the mean normal stress. Suppose that shear fail-

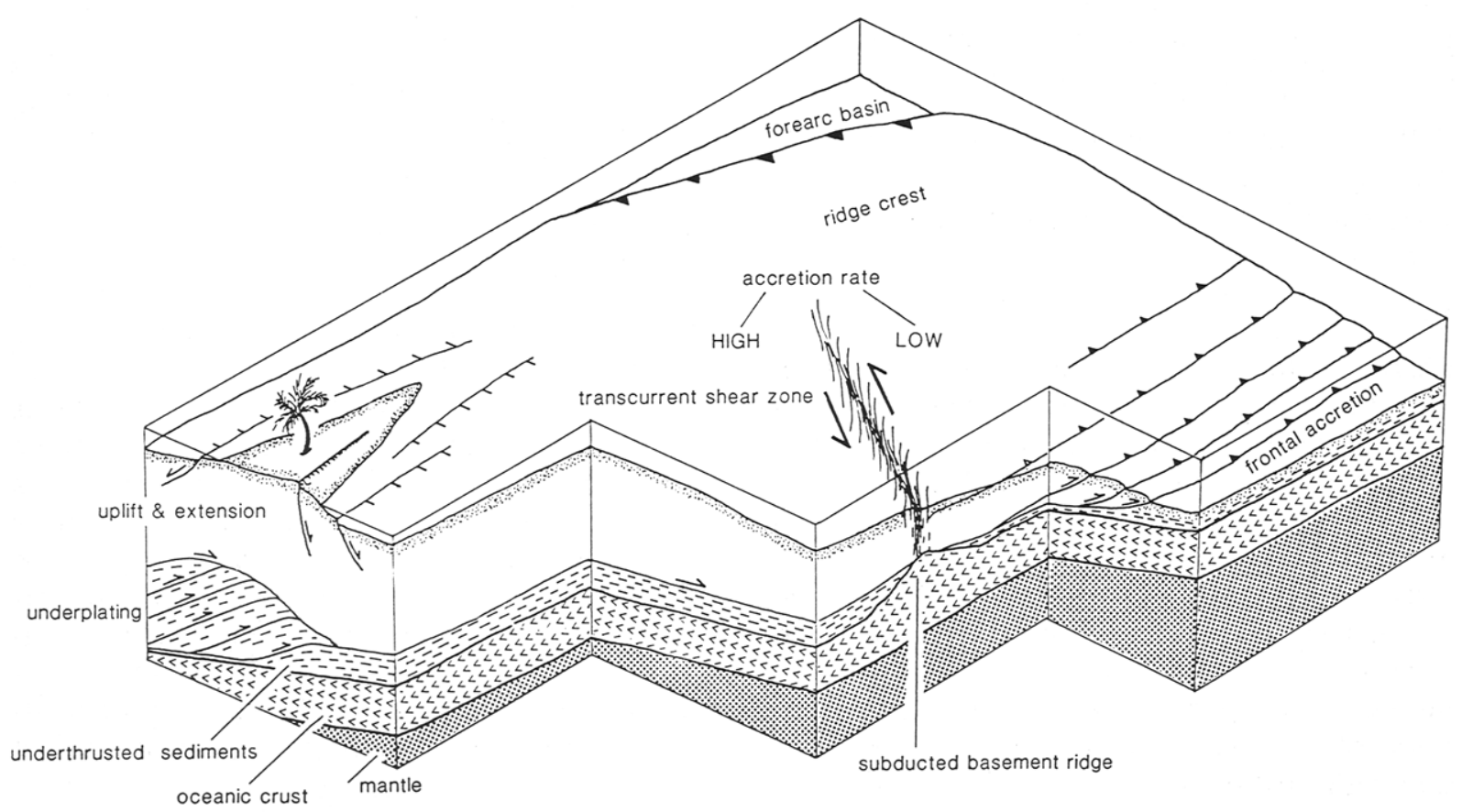

Fig. 1. Cartoon of macroscopic deformational features associated with an active accretionary wedge. Thrusting and lateral shortening is associated with frontal accretion and wedge-building. Wrench faults separate terrains of different accretion rate. Normal faults develop in the uplifted hanging wall of underplated material. 
a

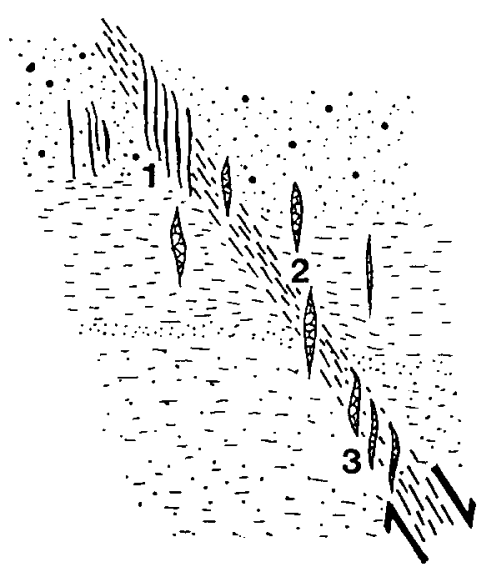

b

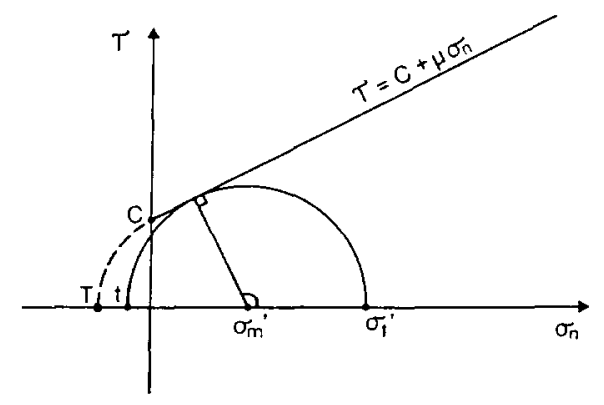

Fig. 2. (a) The geometry of a shear zone and associated hydrofractures in real space: $1=$ mud-filled veins, $L=$ single caroonate-cemented veins, $3=$ en-echelon array of carbonate-cemented veins. (b) The critical condition for reopening of hydrofractures and associated shear failure in a Mohr space representation. $T$ denotes the tensile strength of the intact rock, the dashed line between $C$ and $T$ is part of the failure envelope. $t$ is the tensile strength of weakly cemented hydrofractures. For further discussion see text.

ure of the sediment is governed by a law of Coulomb form (see Fig. 2b):

$\tau=C+\mu \sigma_{\mathrm{m}}^{\prime}$

Here $\tau$ is the shear strength, $C$ is the cohesion and $\mu$ is the coefficient of friction. Rewritten in terms of the maximum $\left(\sigma_{1}^{\prime}\right)$ and minimum $\left(\sigma_{3}^{\prime}\right)$ effective principal stresses [14], $\sigma_{1}^{\prime}$ at failure is:

$\sigma_{1}^{\prime}=2 K C+K^{2} \sigma_{3}^{\prime}$

Here $K=\left(1+\mu^{2}\right)^{1 / 2}+\mu$.

Tensional failure, or hydrofracture, is governed by:

$\sigma_{3}^{\prime}=-t$

where $t$ is the tensile strength of the hydrofracture. For the case of an already existing hydrofracture this is the normal tensile stress required to reopen it. It is supposed that hydrofractures can repeatedly open and close, and that they can be easily formed due to pre-deformational structural imperfections in the rock. The tensile strength across existing hydrofractures is assumed to be small in comparison with the cohesion and the tensile strength of the surrounding rock because of the lack of cementation of most fractures [15]. Hydrofracturing always requires $\sigma_{3}^{\prime}<0$ and $C>0$, which means that fractures cannot develop adjacent to completely cohesionless faults.
We now assume that one of the principal stresses is oriented vertically, which is a valid approximation for near-surface faulting. For thrusting $\sigma_{3}^{\prime}$ is vertical, for wrench faulting $\sigma_{2}^{\prime}$ is vertical, and for normal faulting $\sigma_{1}^{\prime}$ is vertical. Strictly this refers to the three basic modes of faulting [11], which may be a valid approximation for the upper few kilometres of the earth's crust. As the ratio of fluid to overburden pressure $\left(\lambda_{v}\right)$ is defined as:

$\lambda_{v}=\frac{P}{\rho g h}=\frac{P}{\sigma_{\text {vertical }}}$

where $\rho$ is the average rock density, $g$ is the gravitational acceleration, and $h$ is depth. The critical stress condition for simultaneous shear failure and hydrofracture is such that the Mohr circle touches the envelope for shear failure and the tensile strength on the Mohr diagram (Fig. 2b). Note that there is an upper limit to the differential stress at which hydrofracturing can take place. Above this value any dilatancy improving the permeability of the rocks has to be induced by cataclastic flow. Using eq. 4 , the condition for hydrofracturing during thrust faulting is:

$\lambda_{v}=1+\frac{t}{\rho g h}$ 
TABLE 1

Mechanical parameters of the model rocks

\begin{tabular}{lrr}
\hline Rock type & Soft & \multicolumn{1}{c}{ Hard } \\
\hline Coefficient of friction & 0.32 & 0.50 \\
$K$ & 1.37 & 1.62 \\
Density $\left(\mathrm{g} / \mathrm{cm}^{3}\right)$ & 2.00 & 2.00 \\
Cohesion $(\mathrm{MPa})$ & 0.50 & 5.00 \\
Tensional strength $(\mathrm{MPa})$ & -0.05 & -1.00 \\
Maximum differential stress & & \\
$\quad$ for hydrofracture $(\mathrm{MPa})$ & 1.41 & 17.80 \\
\hline
\end{tabular}

For wrench faulting from eqs. 3 and 4:

$\lambda_{v}=1-\frac{K C-t / 2\left(K^{2}+1\right)}{\rho g h}$

and for normal faulting:

$\lambda_{\mathrm{v}}=1-\frac{2 K C-K^{2} t}{\rho g h}$

Fig. 2a shows how hydrofractures are expected to develop in and around fault zones in argilla- ceous rocks in real space. The first frequent case depicted (1) are mud-fiiled veins [15,16] which may occur as en-echelon arrays or interlocking networks. Carbonate-filled veins $(2,3)$ have also been described in the literature [5,17]. Most hydrofractures, however, may be non-permanent structural features, as fossilisation requires the action of solution-deposition processes or fluidisation of the mud surrounding the fractures.

\section{Predictive behaviour of soft and indurated muds}

From eqs. $6-8$, fields of potential shear failure and hydrofracture can be delineated for the three different modes of faulting. Probably most useful are plots of $\lambda_{v}$ versus depth (Fig. 3), where the graphs separate fields of potential hydrofracture from those where hydrofracture cannot occur. For thrusting and hydrofracture $\lambda_{\mathrm{v}}$ must always be greater than unity.

We consider two "model" rocks (Table 1) with mechanical properties that are thought to repre-
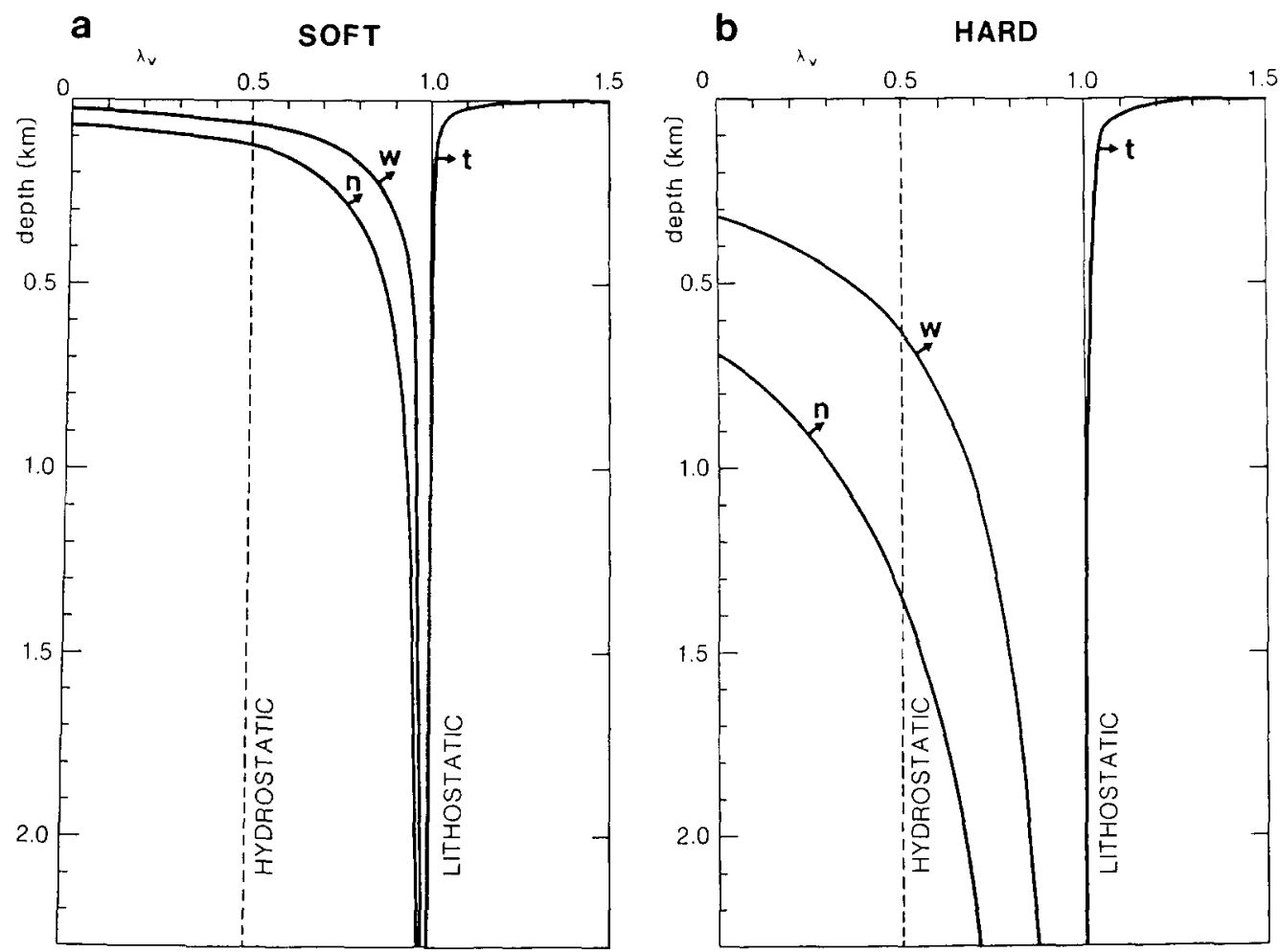

Fig. 3. Potential fields of hydrofracture as a function of faulting mode, depth and $\lambda_{\mathrm{v}}$ for the two model rocks. The arrows on the graphs for normal $(n)$, wrench $(w)$ and thrust $(t)$ faulting point to the fields where simultaneous hydrofracture and shear failure is possible. 
sent diagenetic end-member states of argillaceous sediments that have not undergone metamorphism. The "soft" case represents an essentially unmodified sediment, but in the "hard" case significant diagenesis and cementation have occurred. For the sake of simplicity both rocks have densities of $\rho=2.0 \mathrm{~g} / \mathrm{cm}^{3}$. The first one ("soft" in Fig. 3) represents a non-indurated mud with low cohesion, very low tensile strength across hydrofractures and a low coefficient of friction. A value of $\mu=0.32$ for a water-saturated silt/clay mixture appears reasonable from the point of view of soil mechanics [18] and from considerations based on the geometry of the frontal parts of accretionary wedges [19]. The critical differential stress [12] above which hydrofracture cannot occur in this rock is $1.41 \mathrm{MPa}$. The second rock type ("hard" in Fig. 3) is much more cohesive,

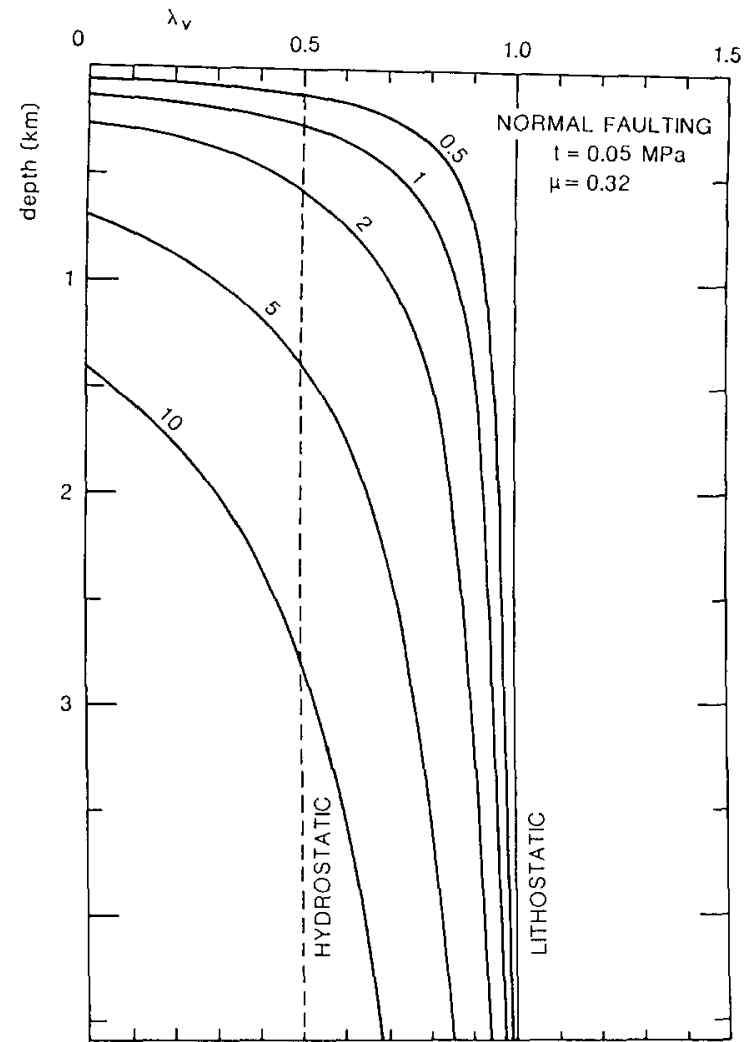

Fig. 4. Variation of potential fields of hydrofracture with variable cohesion. Representation is analogous to Fig. 3. Faulting mode is normal faulting, tensional strength across hydrofractures is $0.05 \mathrm{MPa}$, coefficient of friction is 0.32 , bulk density is $2.0 \mathrm{~g} / \mathrm{cm}^{3}$. Values for cohesion are $0.5,1,2,5$ and $10 \mathrm{MPa}$. has a tensile strength across hydrofractures of 1 $\mathrm{MPa}$ and a coefficient of friction (0.5) that is more akin to that of rocks that have undergone significant pore space reduction and cementation $[18,20]$. For the "hard" model rock, the critical differential stress above which hydrofracture cannot occur is $17.8 \mathrm{MPa}$.

A very important feature of Fig. 3 is that during wrenching and normal faulting of wet rock hydrofracture will invariably accompany shear failure down to certain depths. In the diagrams, these depths are marked by the intersections between the dashed lines showing the hydrostatic head and the lines limiting the fields of potential hydrofracture. This means that the upper sections of wrench faults or normal faults will show increased permeability for fluids during shearing, and thus efficient venting in the case of large-scale hydrostatic pressure gradients. In the case of the soft muds it is the upper $80-120 \mathrm{~m}$, in the case of the hard mudstones it is the upper $650-1400 \mathrm{~m}$ of section. The figures are to be taken as qualitative estimates, but they show that those parts of accretionary wedges that undergo wrenching and normal faulting may be intrinsically "leaky". Fluid pressures exceeding the hydrostatic head are very likely to exist in argillaceous sediment piles for many reasons [21], so that under these conditions hydrofracture-induced venting around normal and wrench fault zones may in fact occur to great depths.

The most important parameter to influence the capability of rocks to hydrofracture during wrenching and normal faulting is cohesion. This is evident from eqs. 7 and 8, and Fig. 4 shows the dependence of maximum depth for hydrofracture as a function of $\lambda_{\mathrm{v}}$ and cohesion. The faulting mode is normal faulting. Other parameters are held constant: tensile strength across the hydrofractures is $0.05 \mathrm{MPa}$, the coefficient of friction is 0.32 , and density is $2.0 \mathrm{~g} / \mathrm{cm}^{3}$. It may not be entirely realistic to keep $t$ constant while varying $C$, but eq. 8 clearly shows that $t$ is a second-order variable. The lines delineate fields of hydrofracture for cohesions of $0.5,1,2,5$ and $10 \mathrm{MPa}$, respectively. Cohesion of rocks increases very much with progressive diagenesis, and therefore as a first-order approximation with depth. Consequently the possible depth range of hydrofracture increases with progressive diagenesis. 


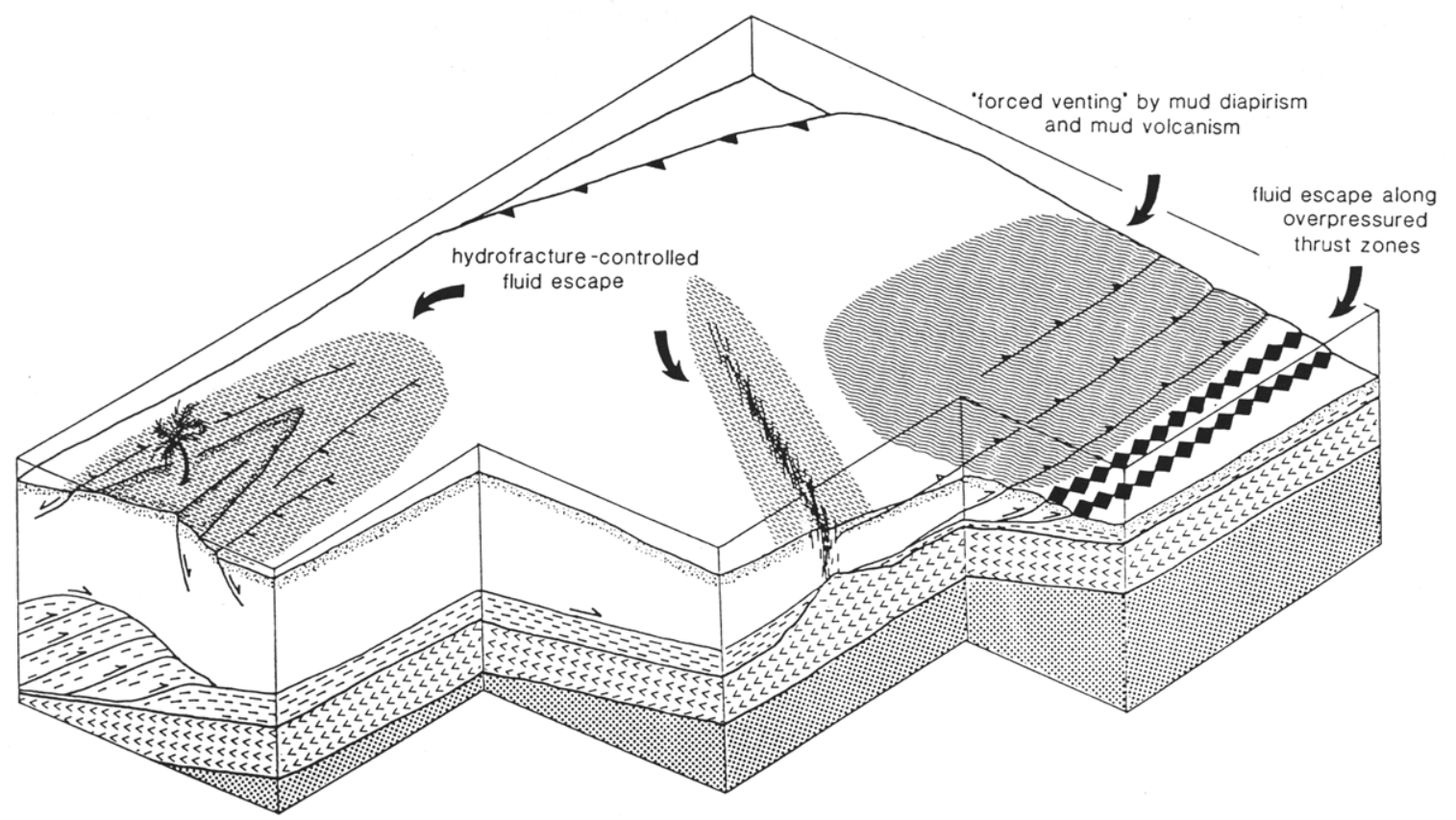

Fig. 5. Cartoon showing different regimes of fluid venting in an active accretionary wedge. See text for discussion.

Hydrofracture associated with thrust faulting always requires fluid pressures in excess of the lithostatic pressure (Fig. 3). The fact that shearing, extensional veining and interstitial fluids of anomalous composition are closely linked in the frontal thrust system of the Barbados accretionary wedge $[5,7]$ is indirect proof that such anomalously high fluid pressures do exist in thrust zones at least locally and episodically. However, in vast parts of accretionary complexes that are subjected to lateral compression, the ratio of fluid to overburden pressure may be somewhat less than 1 [8], resulting in non-hydrofractured argillaceous rock sequences that have low permeabilities in spite of active deformation.

\section{Geological implications}

The first point to consider here is the localisation of different fluid venting processes in accretionary wedges. From the previous section it follows that regions undergoing uplift and gravitational collapse or significant transcurrent faulting have a system of deep-reaching fluid conduits in the form of constantly or at least intermittently permeable faults (see Fig. 5). These regions are unlikely to maintain high fluid pressures in the long term. Regions of lateral compression and thrusting are either characterised by suppressed venting (in the case of $\lambda_{v}<1$ ) or fault zone bound venting (for $\lambda_{v}>1$ ) (Fig. 5). The region of frontal imbrication in the Barbados accretionary complex, especially in the drilling area of DSDP $78 \mathrm{~A}$ and ODP 110 (Fig. 6), is a documented example of thrust zone bound venting $[4,7]$. This may at least in part explain the $2-9 \%$ porosity loss in the accreted sections with reference to their undeformed counterparts [22]. If fluid venting is suppressed, thrusting will invariably cause the burial of unconsolidated sections of sediment in the footwall of normally consolidated sediment. The resulting density inversion may lead to mud diapirism and mud volcanism. Note that according to the line of reasoning developed above, mud diapirism and mud volcanism would have to be confined to those parts of accretionary wedges that are undergoing lateral shortening with ratios of fluid and lithostatic pressures less than one (Fig. 5).

Mud diapirism has been reported from many active accretionary wedges. The example best documented by submarine mapping is that of the Barbados fore-arc [23] (Fig. 6). Here it is obvious that the occurrence of mud diapirs and mud 
volcanoes (dots in Fig. 6) is largely restricted to the southeastern part of the accretionary wedge. This part constitutes the area of high rates of accretion and underthrusting in a regime of over- all lateral shortening. Mud diapirs are often emplaced along thrusts and reverse faults [23-25].

Mud diapirism is very rare in areas of "reflective seabed" (Fig. 6). Reflective seabed was iden-

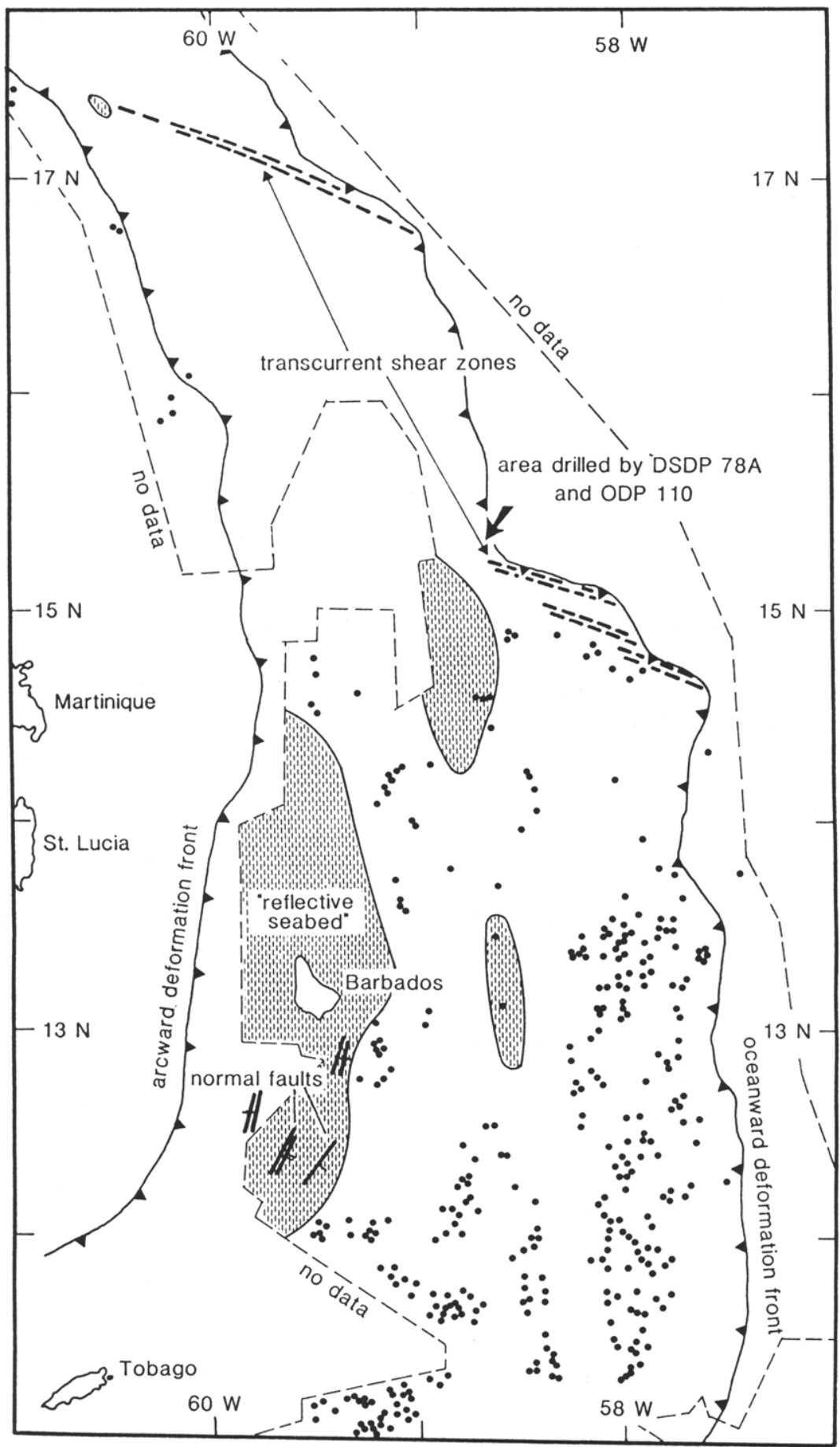

Fig. 6. Sketch map of the Barbados accretionary wedge, after Brown and Westbrook [23]. Dots show the locations of active mud diapirs and mud volcanoes. 
tified during GLORIA surveys. Its exact origin is as yet unclear, but it has been interpreted [23] to correspond to outcrops of accreted rocks, apparently stripped off their cover of slope sediments in places. Around Barbados Island, reflective seabed is in an area of pronounced surface slopes, scarps and normal faults. Normal faults have not been identified on Barbados [26] but in the areas south [23] and north [27] of the island. These observations are hints that the accreted rocks around Barbados Island have been subjected to gravity-driven extensional deformation at least in the latest stages of their history, and may represent a "vented" part of the accretionary wedge. A possible driving mechanism for this process could be provided by large-scale underplating of deeply underthrust sediments and associated uplift of the tectonic hanging wall in the way depicted in Fig. 5.

In the Barbados accretionary prism, mud diapirism is also absent in areas that can be identified as undergoing transcurrent shearing (Fig. 6). Looking beyond the Barbados accretionary prism, mud diapirs off the eastern coast of Trinidad are either located in areas of transpressive deformation or on the stable Orinoco shelf southeast of the deformation front [28]. The occurrence of mud diapirs outside the deformed South American-Caribbean plate boundary zone indicates that overthrusting is not the only mechanism to trigger the formation of mud diapirs. They may equally well be related to the copious influx of sediment in this area, especially in the Miocene. Thus the absence or presence of mud diapirs cannot be used as sole criterion to identify a particular tectonic regime.

I speculate that the venting capabilities of different parts of accretionary wedges may also be crucial for hydrocarbon migration and trapping. Migration along hydrofractured normal faults or wrench faults is very likely to lead to hydrocarbon loss, and probably does not significantly contribute to formation of economic accumulations of hydrocarbons. Terrains with a continuous history of lateral shortening are probably more prospective.

\section{Conclusions}

Accretionary wedges show frequent evidence for simultaneous hydrofracture and shear failure in zones of active deformation. In argillaceous rock sequences, this is the only way to enhance permeability and aid migration of fluid out of the sediment pile. The capability of rocks to hydrofracture during shearing critically depends on the mode of faulting and effective mean stress. The depth to which hydrofracture can occur, is a function of both faulting mode and the ratio of fluid and lithostatic pressures $\left(\lambda_{v}\right)$. Wrench faults and normal faults can show associated hydrofracture and permeability increases to great depths even at $\lambda_{v}$ significantly less than one, whereas thrust faults always require $\lambda_{\mathrm{v}}$ to be greater than one. Consequently, those parts of accretionary wedges that undergo wrench or normal faulting are likely to be efficiently vented. Zones of lateral shortening show suppressed venting unless fluid pressures are permitted to rise above the lithostatic head. Otherwise there is formation of thick, underconsolidated and buoyant sections of rock in the footwalls of thrusts that give rise to deformation-induced mud diapirism and mud volcanism. The hydrocarbon potential of regions that show a history of continuous lateral shortening and thrusting probably has to be rated higher than that of regions with a record of wrenching and normal faulting.

\section{Acknowledgements}

I have learnt much about mudrocks during discussions with Kevin Brown, Warner Brückmann, Yujiro Ogawa, David Prior and Janos Urai. Casey Moore and two anonymous reviewers gave constructive criticisms and suggested valuable improvements of this paper.

\section{References}

1 C.J. Bray and D.E. Karig, Porosity of sediments in accretionary prisms and some implications for dewatering processes, J. Geophys. Res., 90, 768-778, 1985.

2 M.S. Marlow, H.J. Lee and A.W. Wright, Physical properties of sediment from the Lesser Antilles margin along the Barbados Ridge; results from Deep Sea Drilling Project Leg 78A, Proc. ODP, Sci. Results, 78A, 549-558, 1984.

3 E. Taylor and J. Leonard, Sediment consolidation and permeability at the Barbados forearc, Proc. ODP, Sci. Results, 110, 289-308, 1990

4 J.C. Moore, A. Mascle, E. Taylor, P. Andreieff, F. Alvarez, R. Barnes, C. Beck, J. Behrmann, G. Blanc, K. Brown, M. Clark, J. Dolan, J. Gieskes, A. Fisher, M. 
Hounslow, P. McLellan, K. Moran, Y. Ogawa, T. Sakai, J. Schoonmaker, P. Vrolijk, R. Wilkens and C. Williams, Expulsion of deep-sourced fluids along subduction zone decollement, northern Barbados ridge, Nature, 326, 785$788,1987$.

5 J.H. Behrmann, K. Brown, J.C. Moore, A. Mascle, E. Taylor, P. Andreieff, F. Alvarez, R. Barnes, C. Beck, G. Blanc, M. Clark, J. Dolan, J. Gieskes, A. Fisher, M. Hounslow, P. McLellan, K. Moran, Y. Ogawa, T. Sakai, J. Schoonmaker, P. Vrolijk, R. Wilkens and C. Williams, Evolution of structures and fabrics in the Barbados Accretionary Prism. Insights from Leg 110 of the Ocean Drilling Program, J. Struct. Geol., 10, 577-591, 1988.

6 J. Gieskes, G. Blanc, P. Vrolijk, J.C. Moore, A. Mascle, E. Taylor, P. Andreieff, F. Alvarez, R. Barnes, C. Beck, J. Behrmann, K. Brown, M. Clark, J. Dolan, J., A. Fisher, M. Hounslow, P. McLellan, K. Moran, Y. Ogawa, T. Sakai, J. Schoonmaker, R. Wilkens and C. Williams, Hydrogeochemistry in the Barbados accretionary complex, Palaeogeogr. Palaeoclimatol. Palaeoecol., 71, 83-96, 1989.

7 A. Mascle and J.C. Moore, ODP Leg 110: tectonic and hydrologic synthesis, Proc. ODP, Sci. Results, 110, $409-$ 422,1990 .

8 D. Davis, J. Suppe and F.A. Dahlen, Mechanics of foldand-thrust belts and accretionary wedges, J. Geophys. Res., 88, 1153-1172, 1983.

9 W.M. Chapple, Mechanics of thin skinned fold-and-thrust belts, Geol. Soc. Am. Bull., 89, 1189-1198, 1978.

10 J.P. Platt, Dynamics of orogenic wedges and the uplift of high pressure metamorphic rocks, Geol. Soc. Am. Bull., 97, 1037-1053, 1986.

11 E.M. Anderson, The Dynamics of Faulting and Dyke Formation with Applications to Britain, 206 pp., Oliver and Boyd, Edinburgh, 1951.

12 R.H. Sibson, Controls on low-stress hydro-fracture dilatancy in thrust, wrench and normal fault terrains, Nature, $289,665-667,1981$.

13 M.K. Hubbert and W.W. Rubey, Role of fluid pressure in mechanics of overthrust faulting, I. Mechanics of fluidfilled porous solids and its application to overthrust faulting, Geol. Soc. Am. Bull., 70, 115-166, 1959.

14 R.H. Sibson, Fault rocks and fault mechanisms, J. Geol. Soc. London, 133, 191-213, 1977.

15 R.J. Knipe, Microstructural evolution of vein arrays preserved in DSDP cores from the Japan Trench, Leg 57, in: Structural Fabrics in DSDP Cores from Forearcs, J.C. Moore, ed., Geol. Soc. Am. Mem., 166, 75-88, 1986.
16 Y. Ogawa, Beard-like veinlet structure as fracture cleavage in the Neogene siltstone in the Miura and Bosa Peninsulas, central Japan, Sci. Rep. Dept. Geol. Kyushu Univ., 13, $321-327,1980$.

17 K.M. Brown and J.H. Behrmann, Genesis and evolution of small scale structures in the toe of the Barbados Ridge, Proc. ODP, Sci. Results, 110, 229-244, 1990.

18 J.K. Mitchell, Fundamentals of Soil Behaviour, 422 pp., Wiley, New York, 1976

19 D.E. Karig, Physical properties and mechanical state of accreted sediments in the Nankai Trough, Southwest Japan Arc, in: Structural Fabrics in DSDP Cores from Forearcs, J.C. Moore, ed., Geol. Soc. Am. Mem., 166, 117-133, 1986.

20 J.C. Jaeger and N.G.W. Cook, Fundamentals of Rock Mechanics, 593 pp., Chapman and Hall, London, 1979.

21 T.N. Narasimhan, W.N. Houston and A.M. Nur, Penrose conference report: the role of pore pressure in deformation in geologic processes, Geology, 8, 349-351, 1980.

22 W. Brückmann, Porosity modeling and stress evaluation in the Barbados Ridge Accretionary Complex, Geol. Rundsch., 78, 197-205, 1989.

23 K.M. Brown and G.K. Westbrook, The tectonic fabric of the Barbados Ridge accretionary complex, Mar. Pet. Geol., 4, 71-81, 1987.

24 P. Valery, G. Nely, A. Mascle, B. Biju-Duval, P. Le Quellec and J.L. Berthon, Structure et croissance d'un prisme d'accrétion tectonique proche d'un continent: la Ride de la Barbade au Sud de l'arc antillais, in: Géodynamique des Caraibes, A. Mascle, ed., pp. 173-186, Editions Technip, Paris, 1985

25 A. Mascle, L. Endignoux and T. Chennouf, Frontal accretion and piggyback basin development at the southern edge of the Barbados Ridge accretionary complex, Proc. ODP, Sci. Results, 110, 17-28, 1990.

26 R.C. Speed, Structure of the accretionary complex of Barbados, I. Chalky Mount, Geol. Soc. Am. Bull., 94, 92-116, 1983.

27 R. Torrini, Jr. and R.C. Speed, Tectonic wedging in the forearc basin-accretionary prism transition, Lesser Antilles Forearc, J. Geophys. Res., 94, B8, 10549-10584, 1989.

$28 \mathrm{P}$. Robertson and K. Burke, Evolution of Southern Caribbean plate boundary, vicinity of Trinidad and Tobago, Am. Assoc. Pet. Geol. Bull., 73, 490-509, 1989. 